Karolina Lachowska

ORCID: 0000-0003-3659-6785

Uniwersytet Wrocławski

https://doi.org/10.19195/1733-5779.38.16

\title{
Dekontekstualizacja ram interpretacyjnych „terroryzm” i „11 września”
}

\author{
Świat, który przeżywamy, jest taki i musi być taki, jaki jest, \\ ponieważ my go takim zrobiliśmy. \\ Ernst von Glasersfeld
}

Słowa kluczowe: terroryzm, media, rama interpretacyjna, mediatyzacja

Keywords: terrorism, media, interpretive frame, mediatization

Abstrakt: Punktem wyjścia niniejszych rozważań jest koncepcja mediów masowych Niklasa Luhmanna mówiąca, że dla współczesnych zmediatyzowanych społeczeństw media są podstawowym źródłem wiedzy o świecie. Reprezentują one i konstruują szczególnie te obszary życia, do których jako odbiorcy nie jesteśmy w stanie bezpośrednio dotrzeć. Przyjęto zatem, że pojęcie terroryzmu, przez zaimplikowany potencjał reprodukcji tematycznej, wykorzystywane jest w kontekście innych wydarzeń, niekoniecznie z nim związanych. W niniejszym artykule podjęta została próba określenia zakresów wykorzystywania ram interpretacyjnych w komunikacji medialnej i politycznej. Autorka przedstawiła rolę mediów w procesie wytwarzania ram „terroryzm” i „11 września”, wskazała konteksty, w których ramy te są uruchamiane, a następnie podjęła się odpowiedzi na pytanie: jaką funkcję pełnią tego typu konteksty odnoszące się do terroryzmu.

\section{Decontextualization of the interpretive framework "terrorism" and 9/11}

Abstract: The starting point of the deliberations is Niklas Luhmann's mass media conception which states that the media are the fundamental source of knowledge about the world for the contemporary mediatized societies. The media represent and construct particularly those domains of life to which we, as the observers, do not have a direct contact. The author assumed that the concept of 'terrorism', through the implied potential of thematic reproduction, is employed with connection with hardly or non-related with terrorism. The article attempts to define the scope of employing the interpretative frames in media and political communication. The author tries to show the role of media in the construction of the frames ' $9 / 11$ ' and 'terrorism', concentrate on the contexts in 
which two frames are activated, and subsequently answer the question what is the function of such contexts relating to terrorism.

Dwóch mężczyzn uzbrojonych w kałasznikowy 18 marca 2015 roku wtargnęło do budynku Muzeum Bardo w Tunisie i zaczęło strzelać do zwiedzających. Do zamachu przyznało się ISIS, a sam zamach powiązano z innym, dokonanym kilka miesięcy wcześniej w Susie. „To jest chyba taki polski 11 września...” — powiedział dzień później na antenie TVN24 Marek Biernacki, ówczesny przewodniczący Sejmowej Komisji do Spraw Służb Specjalnych. W wyniku zamachu w Tunisie zginęły 24 osoby, a ponad 50 zostało rannych. Biernacki dodał: ,po raz pierwszy taki bezpośredni islamski zamach terrorystyczny dotknął Polaków"2. W przedstawionych wypowiedziach Biernackiego należy zwrócić uwagę na elementy wskazujące na brak wiedzy mówcy lub, co bardziej prawdopodobne, na wywołanie zamierzonego efektu.

W zamachach islamskiej Al-Kaidy na WTC w 2001 roku zginęło prawie 3000 osób - w Tunisie 24, w Nowym Jorku zginęło sześcioro Polaków — w Tunisie trzech $^{3}$. Na podstawie tych informacji słowa Biernackiego uznać można za nieadekwatne do zaistniałej sytuacji. Należy zatem zadać pytanie, w jakim celu zostało, to powiedziane.

Zamachy z 11 września 2001 roku były nie tylko bezprecedensowym wydarzeniem politycznym, lecz także punktem przełomowym procesu mediatyzacji terroryzmu. Stacje telewizyjne niemalże na żywo relacjonowały ich przebieg. Zamachowcy, wykorzystując media, przygotowali strategię umożliwiającą globalną bezpośrednią obserwację drugiej fazy ataku. Tym samym terroryści dostarczyli widzom bezprecedensowy spektakl i po raz pierwszy trafili ze swoim przekazem do tak szerokiej publiczności. Odbiorcy przez uczestnictwo w tragedii zrozumieli, że terroryzm jest zagrożeniem także dla nich. To wydarzenie było początkiem nie tylko nowej epoki w sposobie wyobrażania i definiowania terroryzmu, lecz także swoistym novum w zakresie strategicznego planowania ataków i celów wyznaczanych przez samych zamachowców. Terroryzm stał się medialny. Od wydarzeń w Nowym Jorku w komunikacji na temat terroryzmu pojawiły się podział na okres przed zamachem na WTC i po zamachu, a także określenia „od zamachów na WTC" czy „prawie jak zamach na WTC”. Wydarzenie to, dzięki medialnemu zapośredniczeniu, stało się wydarzeniem medialnym, które reprodukowane w dyskursie medialnym ulegało tradycjonalizacji i zakotwiczyło się w systemie kultury ${ }^{4}$.

1 Biernacki o zamachu w Tunezji: to polski 11 września, TVN24 2015, https://tvn24.pl/polska/ biernacki-o-zamachu-w-tunezji-to-polski-11-wrzesnia-ra525580 (dostęp: 7.06.2021).

2 Ibidem.

${ }^{3}$ Zamach na muzeum $w$ Tunisie - raport, TVN24 2015, https://tvn24.pl/raporty/zamach-na-muzeum-w-tunezji-rr962-2595701 (dostęp: 7.06.2021).

4 M. Fleischer, Ogólna teoria komunikacji, Wrocław 2007, s. 293. 
Warto zaznaczyć, że szeroko pojęty terroryzm jest atrakcyjny dla systemu mediów, ponieważ wpisuje się w selektory informacji Niklasa Luhmanna (zaskoczenie, liczby, konflikty, przekraczanie norm) $)^{5}$, a także ze względu na zaimplikowany potencjał reprodukcji tematycznej. Umieszczanie go w kontekście narracyjnym innych wydarzeń pozwala na budowanie ciągłości i nawiązywalności. Słyszymy o nim zarówno w przypadku wyborów w Polsce, aneksji Krymu, wojny w Syrii, jak i w komunikatach o kontrolach na lotniskach, ofertach wakacyjnych, wyścigu zbrojeń czy prawach kobiet. W ten sposób terroryzm staje się elementem konstrukcji wydarzeń bezpośrednio z nim niezwiązanych, co w konsekwencji nadaje rangę tym wydarzeniom i buduje wśród odbiorców poczucie tego, ,że ciągle coś się dzieje".

Celem niniejszego artykułu jest z jednej strony przybliżenie roli mediów w procesie konstruowania „pojęć”, do których nie mamy bezpośredniego dostępu, z drugiej zaś wskazanie kontekstów i celów uruchamiania wybranych ram interpretacyjnych (wcześniej wytworzonych przez media) przez nadawców. Podjęta zostanie próba odpowiedzi na pytanie postawione w pierwszym akapicie: Dlaczego coś zostało powiedziane?

\section{Systemy społeczne w teorii Niklasa Luhmanna}

Punktem wyjścia niniejszych rozważań jest teoria systemów społecznych Luhmanna, której podstawowym elementem jest operacja rozróżnienia między systemem a środowiskiem, umożliwiająca w konsekwencji wyszczególnienie samoreferencji i referencji obcej (system i środowisko systemu). Systemy społeczne to systemy komunikacyjne, które są operacyjnie zamknięte, ale otwarte poznawczo. Otwartość poznawcza umożliwia co prawda skanowanie i przetwarzanie komunikacji zachodzących w środowisku (ale na prawach własnego kodu binarnego), jednak operacyjna zamkniętość sprawia, że systemy nie mogą wpływać na siebie bezpośrednio ${ }^{6}$. Luhmann implementuje więc do swojej teorii biologiczne zjawisko autopoiezy ${ }^{7}$, które determinuje kwestie poznania, traktowanego jako efekt własnych operacji danych systemów kognitywnych ${ }^{8}$. Luhmannowskie systemy traktowane są więc jako systemy samorefleksyjne, w których „operacje komunikacji nawiązują do wcześniejszych komunikacji i antycypują przyszłe komunikacje"”.

5 Zob. N. Luhmann, Realność mediów masowych, przeł. J. Barbacka,Wrocław 2009, s. 36-42.

${ }^{6}$ Zob. N. Luhmann, Systemy społeczne. Zarys ogólnej teorii, przeł. M. Kaczmarczyk, Kraków 2007.

7 Zob. R.H. Maturana, Ontologia obserwacji. Biologiczne podstawy samoświadomości i fizykalna dziedzina egzystencji, [w:] Radykalny konstruktywizm. Antologia, red. B. Balicki, D. Lewiński, B. Ryż, Wrocław 2010, s. 29-46.

${ }^{8}$ Zob. S.J. Schmidt, Konstruktywizm jako teoria mediów, [w:] Konstruktywizm w badaniach literackich, red. E. Kuźma, A. Skrendo, J. Madejski, Kraków 2006.

9 K. Matuszek, Niklasa Luhmanna socjologia bez człowieka, Kraków 2017, s. 18. 
Systemy społeczne rozumiane są jednocześnie jako systemy funkcjonalne, operujące na podstawie wytworzonego wewnątrzsystemowo systemu norm i reguł. Funkcjonalna dyferencjacja społeczeństwa dążyć ma do redukcji kompleksowości świata, rozumianej jako produkowanie takiej liczby znaczeń, które przekraczają możliwość ich aktualizowania i adaptowania. W konsekwencji na system społeczny składa się wiele subsystemów, na przykład polityka, gospodarka, edukacja, z których każdy działa według własnych, wewnętrznych uwarunkowań, pełniąc przy tym określone funkcje. Każdy z subsystemów konstruuje własną tożsamość przekładającą się na wewnątrzsystemowe kody komunikacyjne oraz semantyki, które wykorzystywane są do reprodukcji tożsamości. Jak wyjaśnia Grażyna Skąpska: „przykładowo, prawo na swój własny użytek rozwija teorię prawa, polityka teorię polityki, ekonomia wolnorynkową teorię rynku i pieniądza" 10 .

Interesujący nas na potrzeby niniejszego artykułu system polityki pełni funkcję polegającą na „utrzymaniu zdolności do podejmowania kolektywnie wiążących decyzji", które stanowią podstawę do podejmowania kolejnych decyzji, nawet kiedy nie osiągnięto porozumienia. Jak każdy system także polityka opiera się na kodzie binarnym, który w tym przypadku przekłada się na relację rządu i opozycji. Komunikacje w systemie polityki określane są jako różnorodne formy decyzyjności, w tym podejmowanie decyzji, przygotowanie do nich, brak decyzji, zapowiadanie decyzji lub jej odwlekanie ${ }^{11}$. Legitymizowanie systemu polityki odbywa się poprzez demokrację, która stanowi odpowiedź na potrzebę samouprawomocnienia się polityki w niezhierarchizowanym społeczeństwie ${ }^{12}$. Rozróżnienie władza/ opozycja dokonywane jest na poziomie preferowanych/akceptowanych wartości, jak dobrobyt, bezpieczeństwo, sprawiedliwość, wolność, równość, solidarność. Przy czym sposób odwoływania się do nich pozwala na konstytuowanie wykluczających się programów politycznych, na przykład: „Kto mówi pokój, nie może koniecznie obstawiać przy sprawiedliwości”, „Kto mówi wolność, musi godzić się na nierówność i vice versa"13. Według Luhmanna system polityki jest operacyjnie zamknięty, zatem decyzje polityczne nie mają bezpośredniej możliwości politycznego sterowania procesami społecznymi. Nie stanowią bezpośredniego odziaływania na inne systemy. Mogą jedynie irytować (działanie powiadamiające) inne systemy za pośrednictwem sprzężeń strukturalnych. Krzysztof Matuszek tłumaczy to następująco: budżet państwa stanowi sprzężenie strukturalne polityki i gospodarki; doradztwo i wiedza ekspercka to sprzężenie strukturalne polityki i nauki. W kontekście komunikacji ważny jest inny typ sprzężenia — symbioza polityki i mediów. Wiadomości i opinia publiczna stanowią sprzężenie strukturalne

${ }^{10}$ G. Skąpska, Niklasa Luhmanna socjologia religii jako element ogólnej teorii systemu społecznego, [w:] N. Luhmann, Funkcja religii, przeł. D. Motak, Kraków 2007, s. 5.

11 K. Matuszek, op. cit., s. 59.

12 Ibidem, s. 60.

13 Ibidem, s. 61. 
systemu polityki i mass mediów ${ }^{14}$. Z jednej strony media uzależnione są od ciągłej produkcji wiadomości politycznych, z drugiej, poprzez sposób narracji utrwalają podział rząd/opozycja, stanowiący podstawę systemu politycznego. Przy czym należy podkreślić, że ze względu na autonomiczność obu systemów wewnętrznie wytwarzane kody mogą być zróżnicowane.

Określenie funkcji mediów w procesie konstrukcji rzeczywistości uznano za istotne $\mathrm{z}$ dwóch powodów. Po pierwsze, wynika to z przyjętego za Luhmannem stanowiska, iż wszystko, co wiemy na temat świata, wiemy z mediów masowych (szczególnie w odniesieniu do tych obszarów życia, do których jako odbiorcy nie jesteśmy w stanie bezpośrednio dotrzeć $)^{15}$. Po drugie, ze względu na przedstawioną relację łączącą media i politykę. Główna funkcja mediów masowych polega na „konstruowaniu rzeczywistości poprzez ciągłe wytwarzanie irytacji jako odchyleń od tego, co znane"16. Jednak komunikacja medialna dochodzi do skutku jedynie wówczas, gdy z komunikacji rozwija się komunikacja. Sama irytacja systemu nie jest komunikacją — musi być ona nie tylko dostrzeżona, lecz także zrozumiana W stopniu umożliwiającym perpetuowanie komunikacji ${ }^{17}$. W swojej teorii systemów Luhmann za podstawowy element uznaje operację rozróżnienia ${ }^{18}$. Różnicowanie jest operacją obserwacji, w której trakcie dokonywane jest rozróżnienie i oznaczenie jednej ze stron rozróżnienia ${ }^{19}$. Innymi słowy, jak wyjaśnia Matuszek:

poznawana rzeczywistość zależy od rozróżnień użytych przez obserwatora, zwłaszcza od rozróżnienia początkowego. [...] Gdy na przykład posługujemy się rozróżnieniem system/środowisko, widzimy coś innego, niż wtedy, gdy stosujemy rozróżnienie całość/część, podmiot/przedmiot albo system/świat przeżywany ${ }^{20}$.

W tym przypadku operacje rozróżnienia są więc obserwacjami mediów. Tak rozumiana obserwacja pozwala na kolejnym poziomie na obserwację obserwacji, czyli identyfikowanie rozróżnień dokonywanych przez media. Obserwacja jest równocześnie poznaniem, jeśli jej efektem są „kondensacja i konfirmacja”21 tożsamości określonych przedmiotów, osób, zjawisk. Poznanie jest jednocześnie aktywnym działaniem, którego efektem jest konstruowanie rzeczywistości dokonywane za pomocą przyjętych rozróżnień. Owe „kondensacja i konfirmacja” tożsamości są w efekcie określoną konstrukcją rzeczywistości. System medialny dostarcza publiczności owe konstrukcje rzeczywistości w postaci ofert medialnych, które mogą być przez odbiorców przyjęte lub odrzucone. Niezależnie jednak od

\footnotetext{
14 Ibidem.

15 N. Luhmann, Realność mediów masowych..., s. 7.

16 K. Matuszek, op. cit., s. 63.

17 N. Luhmann, Realność mediów masowych..., s. 9.

18 Zob. N. Luhmann, Systemy społeczne...

19 Zob. G. Spencer-Brown, Laws of Form, Portland 1994.

${ }^{20}$ K. Matuszek, op. cit., s. 89.

21 Ibidem, s.100
} 
działania odbiorców konstrukcja rzeczywistości zawarta w ofercie medialnej stanowi określone zdefiniowanie rzeczywistości. Jak wyjaśniał Luhmann:

Pod względem kognitywnym musi zatem każda rzeczywistość być konstruowana przy użyciu rozróżnień i pozostaje tym samym konstrukcją. Konstruowana rzeczywistość nie jest więc tą rzeczywistością, którą ma na myśli; i także to jest poznawalne, ale znów tylko poznawalne przy użyciu tego właśnie rozróżnienia ${ }^{22}$.

Mass media tym, co i jak komunikują, wpływają na proces konstrukcji rzeczywistości, wykorzystując jednocześnie określone selektory ${ }^{23}$. Luhmann zauważa, że rosnące skomplikowanie świata wymusza na mediach większą selektywność, co w konsekwencji grozi wytwarzaniem zbyt prostego obrazu świata. Proces selekcji „dekontekstualizuje i kondensuje” określone jednostki i tożsamości, które same w sobie nie mają nic ,tożsamego”. Celem tego procesu jest wytworzenie nawiązywalności, bowiem jedynie to, co identyfikowalne, może być przekształcone w określony schemat i/lub skojarzone z innym schematem. Cechą uboczną tworzenia schematów jest ich generalizacja. Z tego też względu rekonstrukcja medialnej rzeczywistości jest możliwa jedynie poprzez obserwowanie, jak media obserwuja rzeczywistość ${ }^{24}$. Generalizacja i upraszczanie przez media rzeczywistości, w tym politycznej, oparte na schematach i skryptach (pozwalających dotrzeć do szerokiego grona odbiorców), jak kryzys, konflikt, reforma, pozwalają na wytworzenie niepewności społecznej, która może stanowić w polityce źródło władzy ${ }^{25}$. Według Luhmanna: „Ten, kto potrafi mocą swojej decyzji przemienić niepokój innych w poczucie bezpieczeństwa albo lepiej zdefiniować sytuację, zyskuje władzę"26.

\section{Problemy definicyjne terroryzmu}

Aby wskazać sposoby wykorzystania konceptu ,,terroryzmu” w komunikacji, w tym politycznej, należy najpierw przedstawić źródła problemów definicyjnych zjawiska. Terroryzm jest zjawiskiem złożonym ze względu na swoje przyczyny, metody działania oraz cele, w które jest wymierzony. Elementy te są podstawą problemów z jednoznaczną jego identyfikacją. Według specjalistów od terroryzmu międzynarodowego zdefiniowanie zjawiska jest praktycznie niemożliwe, gdyż zakres terminu jest zbyt szeroki ${ }^{27}$. Niejednokrotnie trudno odróżnić terroryzm od zjawisk pokrewnych, w których wykorzystywane są metody stosowane przez terrorystów, funkcjonujących w komunikacji jako odrębne pojęcia — na

22 Cyt. za: ibidem, s. 100.

23 Zob. N. Luhmann, Realność mediów...

24 Ibidem, s. 31-50.

25 K. Matuszek, op. cit., s. 68.

26 Cyt. za: ibidem, s. 69.

27 Zob. S. Wojciechowski, Terroryzm. Analiza pojęcia, „Przegląd Bezpieczeństwa Wewnętrznego" 2009, nr 1, s. 54-60, http://www.abw.gov.pl/portal/pl/92/310/Przeglad_Bezpieczenstwa_ Wewnetrznego_1_2009.html (dostęp: 16.05.2021). 
przykład walka narodowowyzwoleńcza, rewolucja, działania partyzanckie ${ }^{28}$. Podążając tym tropem, problemem jest także odróżnienie na płaszczyźnie komunikacyjnej terroryzmu od zwykłych przestępstw kryminalnych ${ }^{29}$. Metody wykorzystywane przez terrorystów często są stosowane przez organizacje, które nie są grupami terrorystycznymi, na organizacje przykład ekologiczne, anarchistyczne czy grupy przestępcze. Kolejnym elementem stanowiącym o złożoności zjawiska są jego przyczyny i cele. Trudno odzwierciedlić w kilku zdaniach definicji zróżnicowane motywacje terrorystów. Jednak aby odróżnić terroryzm od zwykłego przestępstwa, należy ulokować go w określonym kontekście (ideologicznym, religijnym, politycznym itp.), który jest źródłem impulsów do pewnych działań i z którego często wynikają cele zamachowców. Należy także się zastanowić, czy można usprawiedliwiać działania terrorystyczne. Część krajów rozwiniętych dążyła bowiem do uznania na arenie międzynarodowej metod wykorzystywanych przez terrorystów za przestępstwa kryminalne, niezależnie od motywów. Natomiast inne państwa (na przykład azjatyckie) szukały usprawiedliwienia dla niektórych działań terrorystów, w myśl prawa do samostanowienia narodów (na przykład walk narodowowyzwoleńczych) ${ }^{30}$. Problemy definicyjne potęguje fakt, że istnieją kraje wykorzystujące narzędzia terroryzmu w polityce wewnętrznej oraz wspierające organizacje terrorystyczne. Aktualnie coraz częściej jako terrorystów wskazuje się opozycjonistów, aby w ten sposób umożliwić i usprawnić sądzenie przeciwników władzy (próba wpisania Fundacji Walki z Korupcją Aleksieja Nawalnego przez Rosję na listę organizacji terrorystycznych). Dodatkowo należy zwrócić uwagę na warstwę semantyczną pojęć. Zupełnie odmienne asocjacje, semantykę i wartościowanie mają pojęcia takie, jak ,partyzanci”, „bojownicy o wolność”, ,islami-

28 Zob. D. Casale, Institutional and Legal Aspects of UE Counter-Terrorism, „Legal Aspects Combating of Terrorism" 2008, nr 47, s. 115-129.

29 Przykład: 18 maja 2017 roku były żołnierz amerykańskiej marynarki wojennej Richard Rojas z dużą prędkością wjechał w tłum ludzi na Times Square w Nowym Jorku. W wyniku tego zdarzenia zginęła jedna osoba, a 22 zostały ranne. Po zatrzymaniu Rojas powiedział policjantom: „,chciałem zabić ich wszystkich”. Policja wykluczyła, jakoby incydent miał charakter terrorystyczny (cyt. za: Times Square crash: Man charged said he wanted to , kill them all”, https://www.theguardian.com/us-news/2017/may/19/times-square-crash-man-charged-murder [dostęp: 13.05.2021]). Kolejne przedstawione zdarzenie, o zbliżonym scenariuszu, zostało już sklasyfikowane jako zamach terrorystyczny. Khalid Masood 22 marca 2017 roku na moście Westminsterskim w Londynie wjechał rozpędzonym samochodem w tłum ludzi, a następnie zaatakował nożem policjanta. W wyniku tego zdarzenia zginęło sześć osób, a 49 zostało rannych. Pierwsze komunikaty pojawiające się w mediach wskazywały na zamach terrorystyczny „inspirowany propagandą Państwa Islamskiego”. Policja prowadząca śledztwo w sprawie ataku nie znalazła jednak bezpośrednich powiązań z grupami terrorystycznymi. Do zamachu przyznało się ISIS, nazywając Masooda „,̇̇łnierzem Państwa Islamskiego”. T. Batchelor, Khalid Masood: London attacker had no links to Isis or al-Qaeda, says Met Police, 2017, https://www.independent.co.uk/news/uk/home-news/khalid-masood-london-attack-isis-al-qaeda-no-links-police-a7652696.html (dostęp: 11.05.2021).

30 M. Madej, Międzynarodowy terroryzm polityczny, Warszawa 2001, s. 65. 
ści”, „dżihadyści”, „ekstremiści” czy „, separatyści”, mimo iż w wielu aspektach ich działalność wpisuje się w zakres działalności terrorystycznej. Można zatem założyć, że kontekst wydarzenia determinuje użycie danego terminu, co w konsekwencji przyczynia się do odmiennej semantyzacji i odmiennego wartościowania ${ }^{31}$.

Warto jednak pamiętać, że terroryzm jest zjawiskiem dynamicznym, zmieniającym się w czasie i że nie tylko ewoluuje na poziomie przyczyn i celów obieranych przez grupy, lecz także rozwija się pod względem technologicznym, czego przykładami są cyberterroryzm czy bioterroryzm. Zatem aktualne definicje i wyznaczniki terroryzmu niekoniecznie są adekwatne w stosunku do działań sprzed lat ${ }^{32}$. Przedstawione elementy tworzą jedynie część problemów definicyjnych zjawiska, obrazują jednak jego pojemność zakresową i możliwość negocjowania granic „terroryzmu”, co w konsekwencji może przekładać się na wszelkiego rodzaju nadużycia.

Aktualnie najobszerniejszą stosowaną definicją terroryzmu na arenie międzynarodowej, tym samym przyjętą przez największą liczbę państw ${ }^{33}$, jest definicja zaproponowana w 2002 roku przez Unię Europejską ${ }^{34}$. Dalej przedstawiono pierwszy akt decyzji ramowej Rady UE, odnoszący się bezpośrednio do sposobu interpretacji przestępstwa terrorystycznego rozumianego jako:

a) ataki na życie ludzkie, które mogą powodować śmierć;

b) ataki na integralność cielesną osoby;

c) porwania lub branie zakładników;

d) spowodowanie rozległych zniszczeń obiektów rządowych lub obiektów użyteczności publicznej, systemu transportowego, infrastruktury, włącznie ze zniszczeniem systemu informacyjnego, stałych platform umieszczonych na szelfie kontynentalnym, miejsca publicznego lub mienia prywatnego, mogące zagrozić życiu ludzkiemu lub mogące spowodować poważne straty gospodarcze;

e) zajęcie statku powietrznego, statku lub innego środka transportu publicznego lub towarowego;

f) wytwarzanie, posiadanie, nabywanie, przewożenie, dostarczanie lub używanie broni, materiałów wybuchowych lub jądrowych, broni biologicznej lub chemicznej, jak również badania i rozwój broni biologicznej i chemicznej;

g) uwalnianie substancji niebezpiecznych lub powodowanie pożarów, powodzi lub wybuchów, których rezultatem jest zagrożenie życia ludzkiego;

${ }^{31}$ K. Lachowska, Terroryzm. Definicje i ich funkcje, [w:] Badanie komunikacji, t. 1, Kraków 2018, s. 125.

32 Zob. D. Casale, op. cit., L. Weinberg, A. Pedahzur, S. Hirsch-Hoefler, The Challenges of Conceptualizing Terrorism, „Terrorism and Political Violence” 16, 2004, nr 4, s.777-794.

33 Należy podkreślić, że kraje będące w UE w ramach swoich wewnętrznych przepisów posiadają własne definicje terroryzmu.

34 D. Casale, op. cit., s. 115-129. 
h) zakłócenia lub przerwy w dostawach wody, energii elektrycznej lub wszelkich innych podstawowych zasobów naturalnych, których rezultatem jest zagrożenie życia ludzkiego ${ }^{35}$.

„Będziemy ścigać kraje, które dostarczają pomocy i schronienia terrorystom. Każdy kraj, w każdym regionie świata musi teraz zdecydować: albo jesteście z nami, albo z terrorystami"36. Takimi słowami George W. Bush rozpoczął otwartą „walkę z terroryzmem” po zamachach z 11 września 2001 roku na WTC, tym samym określając USA jako głównego wroga terrorystów. Stany Zjednoczone w ramach swoich struktur wypracowały kilka oficjalnych definicji. Według nich terroryzm to:

- zaplanowane, motywowane politycznie użycie przemocy wobec celów niewalczących, stosowane przez subnarodowe grupy lub tajnych agentów ${ }^{37}$;

- bezprawne użycie siły lub przemocy wobec ludzi lub mienia, celem zastraszenia lub wywarcia przymusu na rząd, ludność cywilną lub części z nich, dążące do osiągnięcia celów politycznych i społecznych ${ }^{38}$;

— zamierzone użycie bezprawnej przemocy (lub groźba jej użycia), mające wywołać poczucie zagrożenia, dążące do zastraszenia rządu lub społeczeństwa, w celu osiągnięcia celów politycznych, religijnych lub ideologicznych ${ }^{39}$.

Powyżej przedstawiono sposoby definiowania terroryzmu przez trzy różne jednostki funkcjonujące w ramach struktur państwowych USA: FBI, CIA, Departament Obrony Stanów Zjednoczonych. Warto zauważyć pojawiające się w nich elementy charakterystyczne dla danego systemu (na przykład ,grupy subnarodowe i tajni agenci” - CIA, ,wywarcie przymusu na rząd, zastraszenie rządu”- FBI), które wynikają z zakresu działalności danej instytucji i ukierunkowują jej pracę.

Chcąc zobrazować różnorodność w sposobie pojmowania terroryzmu, postanowiono przytoczyć wypowiedzi osób powszechnie uznawanych za terrorystów. W 1998 roku Osama bin Laden podczas telewizyjnego wywiadu przedstawił własną definicję terroryzmu:

Ograbiają nas z naszego bogactwa, naszych zasobów naturalnych i ropy. Nasza religia jest pod ostrzałem krytyki. Zabijają i mordują naszych braci. Narażają na szwank nasz honor i godność,

35 Decyzja ramowa Rady Unii Europejskiej z 13 czerwca 2002 roku w sprawie zwalczania terroryzmu, Dz.Urz. UE 2002/475/WSiSW, s. 19, http://eur-lex.europa.eu/legal-content/EN/TXT/?ur $\mathrm{i}=$ uriserv:OJ.L .2002.164.01.0003.01.ENG (dostęp: 16.05.2021).

${ }^{36}$ Transcript of President Bush's address, 2001, http://edition.cnn.com/2001/US/09/20/gen. bush.transcript/ (dostęp: 29.05.2021).

37 Central Intelligence Agency, Terrorism FAQs, 2017, https:/www.cia.gov/news-information/ cia-the-war-on-terrorism/terrorism-faqs.html (dostęp: 15.05.2021).

38 U.S. Department of Justice. Federal Bureau of Investigation, Terrorism 2002-2005, 2017, https://www.fbi.gov/stats-services/publications/terrorism-2002-2005 (dostęp: 29.05.2021).

39 International Terrorism and Security Research, What is Terrorism?, 2017, http://www.terrorism-research.com/ (dostęp: 15.05.2021). 
a gdy ośmielimy się wypowiedzieć, choć słowo protestu przeciwko tej niesprawiedliwości, jesteśmy nazywani terrorystami ${ }^{40}$.

Natomiast Jaser Arafat (przewodniczący Organizacji Wyzwolenia Palestyny) podczas Zgromadzenia Ogólnego ONZ w 1974 roku przekonywał, że:

Różnica między rewolucjonistami a terrorystami leży w sprawie, o którą walczą. Nikt, kto walczy o słuszną sprawę oraz o wolność i niepodległość swojej ziemi, nie może zostać nazwany terrorystą ${ }^{41}$.

Definicje te nie mają sformalizowanego charakteru, stanowią jedynie określony punkt widzenia, a ich funkcjonalność wynika z charakteru działań prowadzonych przez osoby je wygłaszające.

Zgodnie z przyjętą za podstawę teoretyczną artykułu koncepcją komunikacji Luhmanna definicje tworzone są w obrębie systemów, służą ich legitymizacji i zapewniają im ciągłość przez perpetuowanie komunikacji. Porządkują zatem wiedzę o świecie i pełnią określone funkcje w ramach danego systemu. Zgodnie z operacyjnym zamknięciem i otwartością poznawczą systemów autopoietycznych systemy przetwarzają informację pochodzącą ze środowiska, która traktowana jest przez nie jako irytacja systemu, ale sposób jej przetwarzania i nadawania jej znaczenia jest zawsze uzależniony od wewnątrzsystemowych operacji. Przez co sposoby definiowania danego pojęcia przez instytucje mogą się różnić między sobą.

\section{Ramy interpretacyjne}

Założenie Luhmanna, że wszystko, co wiemy o społeczeństwie czy też świecie w ogóle, wiemy z mass mediów ${ }^{42}$, wydaje się wyjątkowo ważne w przypadku zjawisk, do których jako odbiorcy nie mamy bezpośredniego dostępu. Przyjąć zatem należy, że media konstruują rzeczywistość, a proces ten jest tożsamy z procesem nadawania znaczeń w rozumieniu Gerharda Rotha ${ }^{43}$. Jak zauważa Siegfried Schmidt, media coraz częściej wykorzystywane są jako instrumenty tworzenia kognitywnych i komunikacyjnych konstrukcji rzeczywistości, a rosnące skomplikowanie świata wymusza na nich większą selektywność ${ }^{44}$. Wytwarzane w ten sposób oferty medialne nie służą więc transportowaniu „,prawdy” czy „odzwierciedlaniu rzeczywistości”, ale ich podstawowymi kryteriami są ,przydatność/użyteczność" i ,wiarygodność” oparta na „obiektywności”, rozumianej jako ,intersu-

40 Cyt. za: P. Rees, Kolacja z terrorystą. Spotkania z najbardziej poszukiwanymi bojownikami na świecie, przeł. B. Dąbrowa-Kość, G. Kość, Kraków 2008, s. 38.

41 Cyt. za: B. Hoffman, Oblicza terroryzmu, przeł. H. Pawlikowska-Gannon, Warszawa 2001, s. 24.

42 N. Luhmann, Realność mediów masowych..., s.7.

43 Zob. G. Roth, Poznanie i realność: realny mózg i jego rzeczywistość, [w:] Radykalny konstruktywizm..., s. 131-150.

44 S.J. Schmidt, op. cit., s. 326. 
biektywna umowa na temat sposobu konstrukcji rzeczywistości, który może być oczekiwany od dziennikarstwa' ${ }^{25}$. Media, wytwarzając określony obraz świata, posługują się schematami komunikacyjnymi, które określane są jako framing (ramowanie). W konstruktywistycznej teorii społeczeństwa i komunikacji termin ten definiowany jest jako zasady organizacyjne, które są społecznie współdzielone i trwające w czasie, działające w sposób symboliczny w celu strukturyzowania świata społecznego ${ }^{46}$. Dietram A. Scheufele rozróżnia media frames i individual frames. Pierwsze z nich są schematami organizującymi przekazy w mediach (jak mamy o czymś myśleć), natomiast drugie to struktury pojęciowe jednostki umożliwiające przetwarzanie komunikatów ${ }^{47}$. Należy zauważyć, że w przypadku terroryzmu schematy używane przez media będą powielane przez odbiorców z uwagi na brak bezpośrednich doświadczeńn ${ }^{48}$.

Według Roberta M. Entmana ramy funkcjonują w różnych miejscach procesu komunikacyjnego

u nadawcy, który świadomie lub nieświadomie odwołuje się do ram rezydujących w jego systemie przekonań i wierzeń; w tekście, gdzie środki werbalne i ikoniczne sygnalizują istnienie ram; u odbiorcy, który interpretuje komunikat zgodnie z systemem schematów poznawczych istniejących w jego umyśle; w kulturze będącej zbiorem ram przywoływanych w dyskursie ${ }^{49}$.

Niniejsze rozważania koncentrować się zatem będą nie na tym, w jaki sposób stworzona została konkretna rama interpretacyjna, ponieważ na podstawie wcześniejszych badań przyjęto, że wyszczególnione poniżej ramy interpretacyjne są często wykorzystywane przez media i sukcesywnie przez nie nadbudowywane. Celem artykułu będzie sprawdzenie, w jakich kontekstach i w jakim celu uruchamiana jest określona rama interpretacyjna.

\section{Rama interpretacyjna „11 września”, „9/11”}

Zamachy przeprowadzone przez członków Al-Kaidy w USA były najbardziej medialnymi i tragicznymi w skutkach zamachami w historii światowego terroryzmu. W ciągu niecałych dwóch godzin uprowadzono cztery samoloty, z których trzy osiągnęły zamierzone cele. Samolot American Airlines lecący z Bostonu do Los Angeles 11 września o godzinie 8.46 uderzył w północną wieżę WTC. Na pokładzie znajdowało się 81 pasażerów i jedenastu członków załogi. Kilka minut po starcie pięciu terrorystów przejęło nad nim kontrolę i skierowało go w stronę

45 M. Fleischer, Media w perspektywie konstruktywizmu, „2K — Kultura i Komunikacja”2005, nr 1-2, s. 13 .

46 J. Maćkiewicz, Ramy interpretacyjne jako narzędzie badań medioznawczych, „Studia Medioznawcze" 21, 2020, nr 3, s. 619.

47 Ibidem.

48 Zob. K. Lachowska, Kim jest terrorysta? Sposoby stereotypizacji terrorystów. Analiza wyników badań ankietowych, [w:] Badanie i projektowanie komunikacji 4, Kraków 2015.

49 Cyt. za: J. Maćkiewicz, op. cit., s. 619. 
Nowego Jorku. W pełni zatankowany boeing wbił się w północną wieżę WTC, przez co naruszył rdzeń konstrukcji wieżowca. Niecałe dwie godziny później budynek się zawalił. Również kilka minut po starcie samolot United Airlines, także lecący z Bostonu do Los Angeles, z 56 pasażerami oraz dziewięcioma członkami załogi został porwany przez pięciu terrorystów. O godzinie 9.05 maszyna uderzyła w południową wieżę WTC, która zawaliła się 50 minut później ${ }^{50}$. Około godziny 9.00 samolot American Airlines lecący z Herndon do Los Angeles z sześcioma członkami załogi oraz 58 pasażerami na pokładzie, wśród których było pięciu zamachowców, został przejęty i skierowany w stronę Waszyngtonu. Rozbił się o 9.37 w południowo-zachodniej części Pentagonu. W zamachu zginęły 64 osoby będące na pokładzie samolotu oraz 125 osób znajdujących się na terenie Pentagonu. Nie wiadomo, co było celem ostatniego z porwanych samolotów. Boeing United Airlines lecący z Newark do San Francisco, z 37 pasażerami i siedmioma członkami załogi na pokładzie, o godzinie 10.06 rozbił się niedaleko Shanksville w stanie Pensylwania. Początkowo zamachami obarczano Demokratyczny Front Wyzwolenia Palestyny. Informacja ta jednak szybko została zdementowana ${ }^{51}$. W nagraniu dostarczonym do Al-Jazeery do zamachów przyznał się Osama bin Laden, który przekonywał: „Twin Towers były uzasadnionym celem, stanowiącym ekonomiczną potęgę Stanów Zjednoczonych. Zostały zniszczone nie tylko te wieże, ale także wieże moralne tego kraju" ${ }^{52}$. Łącznie w zamachach 11 września zginęły 2783 osoby, a ponad 12 tys. zostało rannych ${ }^{53}$.

Przedstawione tu wydarzenia w wyniku licznych i odpowiednio ukierunkowanych narracji medialnych oraz ciągłe reprodukowanie tychże treści stały się ,wydarzeniami komunikacyjnymi”, które następnie, przez uczestnictwo w różnorodnych dyskursach, stały się częścią kolejnych konstruktów.

W ten sposób dokonywany jest transfer semantyczny z jednego konstruktu wydarzeń na inny, co w konsekwencji tworzy usieciowione i współzależne związki. Elementy konstruktu „11 września 2001” widoczne są w wielu różnych, niejednokrotnie odległych tematycznie aspektach, takich jak: „wojna z terroryzmem”,

50 Federal Bureau of Investigation, Terrorism 2000/2001, http://www.fbi.gov/stats-services/ publications/terror (dostęp: 29.05.2021).

51 America's day of terror: Timeline, BBC News 2001, http://news.bbc.co.uk/2/hi/americas/1537785.stm (dostęp: 29.05.2021).

52 Cyt. za: D. Bamber, Bin Laden: Yes, I did it, „The Telegraph” 2001, http://www.telegraph. co.uk/news/worldnews/asia/afghanistan/1362113/Bin-Laden-Yes-I-did-it.html (dostęp: 29.05.2021).

53 Dane pochodzą ze strony internetowej FBI, zawierającą całkowitą liczbę ofiar zamachów dokonanych 11 września 2001 roku. Federal Bureau of Investigation, Terrorism 2000... W 2002 roku Centers for Disease Control and Prevention przedstawiło szczegółowy raport dotyczący liczby ofiar zamachów na WTC 11 września 2001 roku. Oszacowano ją na 2726 osób. Dokonano podziału według płci, wieku, wykształcenia i narodowości. Centers for Disease Control and Prevention, Deaths in World Trade Center Terrorist Attacks - New York City, „,Morbidity and Mortality Weekly Report" (Weekly Special Issue) 51, 2002, nr 16-18, http://www.cdc.gov/mmwr/preview/mmwrht$\mathrm{ml} / \mathrm{mm} 51 \mathrm{spa6} . \mathrm{htm}$ (dostęp: 29.05.2021). 
„,bezpieczeństwo narodowe/światowe”, „ograniczenia praw człowieka”, „ograniczenia i restrykcje w zakresie swobody przemieszczania się”, „polityka wizowa”.

Nadawcy, odwołując się w swoich wypowiedziach do wydarzeń z 11 września, wykorzystują fakt, że zamachy te były medialne, najtragiczniejsze w skutkach i dosięgnęły potęgi Stanów Zjednoczonych. Powróćmy zatem do pytania postawionego na początku tekstu. Co miała na celu wypowiedź Marka Biernackiego? Autor wypowiedzi chciał uruchomić u odbiorców ramę interpretacyjną „,11 września", budowaną konsekwentnie przez media od 2001 roku. Nieadekwatne porównanie do najtragiczniejszych zamachów w historii terroryzmu miało na celu nadanie rangi wydarzeniu — zamachom w Tunisie. Z kolei odniesienie się do ofiar wśród Polaków należy uznać za próbę osadzenia Polski w kontekście międzynarodowej walki z terroryzmem. Element ten jest o tyle istotny, gdyż według badań przeprowadzonych przez Centrum Badania Opinii Społecznej w 2015 roku (chwilę po zamachach w Tunisie) 56\% zapytanych Polaków wskazało, że ,jest realne zagrożenie zamachami w Polsce". Rok później zaś $42 \%$ badanych w odpowiedzi na pytanie: „Co może zagrozić bezpieczeństwu Polski w najbliższym czasie?” wskazało terrorystów islamskich ${ }^{54}$. Podobnie w 2017 roku jako największą obawę Polacy podawali zamachy terrorystyczne (38\%), dalej pojawili się uchodźcy $(37 \%)$ i wojna $(28 \%)^{55}$. Na podstawie przytoczonych wyników oraz niewystępowania incydentów o charakterze terrorystycznym na terenie Polski można wnioskować, że Polacy boją się potencjalnych zamachów, a tym samym dają możliwość państwu/rządzącym stawiania się w roli gwaranta. Budowanie przez media poczucia zagrożenia terroryzmem pozwala na wytworzenie niepewności społecznej, a ,ten kto, potrafi mocą swojej decyzji przemienić niepokój innych w poczucie bezpieczeństwa albo lepiej zdefiniować sytuację, zyskuje władzę"56. Podobnym porównaniem posłużył się Jarosław Kaczyński w 2014 roku, opisując katastrofę lotniczą w Smoleńsku: „Sprawa jest całkowicie porównywalna z atakiem w Nowym Jorku i Waszyngtonie, z tym słynnym atakiem (z września 2001 roku)"57. Chciał w ten sposób nadać rangę wydarzeniu, pokazać nieudolność ówczesnych władz (dyskredytacja przeciwnika) i wskazać konieczność podjęcia (nowych) działań wyjaśniających katastrofę: „Ustawa przewidywałaby pewne, nawet bardzo daleko idące, możliwości. [...] Oni wtedy zastosowali pewne nadzwyczajne metody i te nadzwyczajne metody powinny także tutaj być zastosowane" ${ }^{, 58}$.

54 Zagrożenie terroryzmem, oprac. M. Feliksiak, CBOS, Komunikat z Badań 2015, nr 50, s. 1.

55 J. Cieśla, Sondaż POLITYKI: czego Polacy boją się najbardziej, „Polityka” 2017, https:// www.polityka.pl/tygodnikpolityka/kraj/1702906,1,sondaz-polityki-czego-polacy-boja-sie-najbardziej.read (dostęp: 27.05.2021).

${ }^{56}$ K. Matuszek, op. cit., s. 69.

57 Kaczyński: Smoleńsk jak 11 września; bez ustawy nie wyjaśnimy katastrofy, TVP Info 2014, https://www.tvp.info/14638157/kaczynski-smolensk-jak-11-wrzesnia-bez-ustawy-nie-wyjasnimy-katastrofy (dostęp: 29.05.2021).

58 Ibidem. 
Po zamachach podczas maratonu w Bostonie (2013) w mediach pojawiały się komentarze: „to najtragiczniejszy w skutkach zamach w USA od czasów zamachów z 11 września” ${ }^{59}$, z kolei po zamachu w Paryżu w 2015 roku dziennik „Le Monde” określił wydarzenie jako „francuski 11 września”60. W wypowiedzi z Bostonu istotny jest element ukazywania WTC jako punktu zwrotnego — od tego czasu nie wydarzyło się nic tragiczniejszego. Należy zaznaczyć, że rama „9/11” uruchamiana jest nie tylko w kontekście zamachów. Odnosząc się do pandemii COVID-19, Donald Trump powiedział: „Przeszliśmy przez najgorszy atak, jaki kiedykolwiek mieliśmy na nasz kraj, to najgorszy atak, jaki kiedykolwiek mieliśmy. [...] To jest gorsze niż Pearl Harbor, to jest gorsze niż World Trade Center"61. Podobne opinie o rozwoju pandemii w USA pojawiły się w amerykańskiej prasie: „Nigdy nie sądziłem, że Nowy Jork może doświadczyć czegoś gorszego niż ataki terrorystyczne z 11 września 2001 roku. Myliłem się"62, „11 września był niszczycielski i tragiczny, [...] teraz też tracimy wielu nowojorczyków, z powodu tego cichego zabójcy, który sieje spustoszenie w społeczności z tą samą przypadkowością i tak samo złowieszczo, jak 11 września" (wypowiedź gubernatora Nowego Jorku Andrew Cuomo) ${ }^{63}$. Gdy 30 marca 2020 roku statek USNS Comfort zadokował w Nowym Jorku, aby pełnić funkcję szpitala dla pacjentów z koronawirusem, w mediach pojawiły się nawiązania: „statek szpitalny został wysłany do Nowego Jorku po raz pierwszy od 11 września” ${ }^{4}$, „ostatni raz, kiedy Comfort dostał sygnał SOS z Nowego Jorku, miał miejsce 11 września" ${ }^{65}$. W tych przykładach widoczne jest zatem $z$ jednej strony nadawanie rangi wydarzeniom (,to jest bardzo istotne"), z drugiej zaś swoistego rodzaju stopniowanie skutków wydarzeń (,to jest najtragiczniejsze”).

59 Dżochar Carnajew uznany za winnego zamachu w Bostonie, Wirtualna Polska 2015, https:// wiadomosci.wp.pl/dzochar-carnajew-uznany-za-winnego-zamachu-w-bostonie-602526808443 7633a (dostęp: 26.05.2021).

60 J. Bellver, ,Le 11 septembre français” à la Une du „,Monde”, pas un mot à la Une en deuil de ,,M,", 2015, https://www.ozap.com/actu/-le-11-septembre-francais-a-la-une-du-monde-pas-unmot-a-la-une-en-deuil-de-m/460911 (dostęp: 27.05.2021).

61 Trump says coronavirus worse 'attack' than Pearl Harbor, BBC News 2020, https://www. bbc.com/news/world-us-canada-52568405 (dostęp: 27.05.2021).

62 M. Boot, I saw 9/11 in New York. This is worse, „Washington Post” 2020, https://www.washingtonpost.com/opinions/2020/04/02/i-saw-911-new-york-this-is-worse/ (dostęp: 27.05.2021).

63 K. Breuninger, New York Gov. Andrew Cuomo says he's 'not that confident' in federal government's handling of coronavirus crisis, 2020, https://www.cnbc.com/2020/04/09/coronavirusupdate-cuomo-not-confident-in-feds-handling-of-crisis.html (dostęp: 27.05.2021).

${ }^{64}$ Crowds Greet USNS Comfort in NYC Monday; Ship to Help Hospitals With Non-Coronavirus Patients, NBC New York, https://www.nbcnewyork.com/news/local/usns-comfort-arrives-innyc-monday-to-help-hospital-with-non-coronavirus-patients/2350317/ (dostęp: 28.05.2021).

65 P. Williams, On the U.S.N.S. Comfort, the Fight Changes Constantly, „The New Yorker” 2020, https://www.newyorker.com/magazine/2020/04/27/on-the-usns-comfort-the-fight-changesconstantly (dostęp: 28.05.2021). 
Kolejnym elementem, do którego zobrazowania wykorzystywana jest rama „9/11”, są liczby, w tym pokazanie skali i ogromu zniszczeń. W 2005 roku specjaliści, ostrzegając świat przed kolejnym atakami terrorystycznymi na skalę WTC, podkreślali, że „11 września zamachowcy praktycznie gołymi rękami uzyskali efekt porównywalny do detonacji ładunku jądrowego, wykorzystując w roli bomb wypełnione paliwem samoloty"66. W sierpniu 2005 roku, gdy w południowo-wschodnie wybrzeże USA uderzył huragan piątej kategorii Katrina, nikt nie zakładał, że okaże się on jednym z najtragiczniejszych w skutkach w historii Stanów Zjednoczonych. W jego konsekwencji zniszczone zostało 80\% Nowego Orleanu, a prawie 1800 osób zostało zabitych ${ }^{67}$. Huragan ten określany był jako „,najtragiczniejszy, ale i najkosztowniejszy, z punktu widzenia ubezpieczycieli, jaki nawiedził Stany Zjednoczone. Dotychczas największe odszkodowania wypłacone zostały tylko po zamachach z 11 września 2001 roku"68. Kolejnym celem uruchamiania ramy 9/11 jest pokazanie skalowalności liczby ofiar. Na początku pandemii, w marcu 2020 roku, w amerykańskich mediach pisano, że ,koronawirus zabił teraz (dotychczas) więcej osób w USA niż ataki terrorystyczne z 11 września”, wraz z rozwojem pandemii media w swojej narracji przeszły od danych zbiorczych do statystyk dziennych, cały czas traktując zamachy w Nowym Jorku jako punkt odniesienia: „dzienna liczba ofiar śmiertelnych COVID-19 w USA przekracza 3000 — więcej niż liczba ofiar śmiertelnych tragedii z 11 września"69.

W Stanach Zjednoczonych wydarzenia z Nowego Jorku przywoływane są także w celu dyskredytowania aktualnej władzy i/lub przeciwników politycznych. Odwołania do efektów ataków wykorzystywane są do obarczania decydentów winą za największą katastrofę w dziejach kraju, której rzekomo można było zapobiec. Podczas prawyborów 2016 roku Trump wskazał winnych za zamachy z 11 września: „World Trade Center upadło, ponieważ Bill Clinton nie zabił Osamy bin Ladena, kiedy miał szansę go zabić. A George Bush... nawiasem mówiąc... George Bush też miał szansę i nie posłuchał rad CIA" ${ }^{\text {70 }}$. Wskazując w sposób jednoznacz-

66 E. Bendyk, Wzór na terror, „Polityka” 2005, https://www.polityka.pl/archiwumpolityki/ 1832788,1,wzor-na-terror.read (dostęp: 28.05.2021).

67 J. Brunkard, G. Namulanda, R. Ratard, Hurricane Katrina Deaths, Louisiana, 2005, „,Disaster Medicine and Public Health Preparedness" 2, 2008, nr 4, s. 215, https:/www.cambridge.org/ core/journals/disaster-medicine-and-public-health-preparedness/article/hurricane-katrina-deaths-louisiana-2005/8A4BA6D478C4EB4C3308D7DD48DEB9AB (dostęp: 30.05.2021).

68 Stona Katrina, „Polityka” 2005, https://www.polityka.pl/archiwumpolityki/1866434,1,slona-katrina.read?fbclid=IwAR3t 543YLwFdQJ5hzNVAZzU0S1i0zh7Rb_oZhDV6mOqNshm3MkIfBudbUMPolityka (dostęp: 30.05.2021).

69 A. Haroun, Daily COVID-19 death toll in the US passes 3,000 - more than the death toll from the 9/11 tragedy, 2020, https://www.businessinsider.com/daily-us-covid-19-deaths-higherthan-911-death-toll-2020-12?IR=T (dostęp: 30.05.2021).

70 S. Osborne, Trump says 'I think I know' who was behind 9/11 attacks, ,Independent” 2020, https://www.independent.co.uk/news/world/americas/us-politics/trump-911-iraq-world-trade-center-deep-state-abc-news-interview-a8962081.html (dostęp: 30.05.2021). 
ny winnych za ataki, Trump nakierowuje odbiorcę na konkretne obrazy powielane przez media, w tym samoloty wbijające się w wieże WTC, George’a W. Busha dowiadującego się podczas spotkania z uczniami na Florydzie o zamachach ${ }^{71} \mathrm{czy}$ słowa Billa Clintona wypowiedziane 10 września 2001 roku: „Osama bin Laden to bardzo sprytny człowiek. Spędziłem wiele czasu, myśląc o nim — i już raz prawie go miałem. Mogłem go zabić" 72 . Koncept 9/11 nie jest jedynym służącym do dyskredytowania przeciwników politycznych. Na przykład polscy politycy również posługują się ramą ,terrorysta-islamista” lub ogólniejszą „terroryzm” (dokładnie zostaną one opisane w dalszej części artykułu).

Kolejnym kontekstem, w którym wykorzystywany jest konstrukt 9/11, jest legitymizacja podjętych działań, w szczególności tych szeroko dyskutowanych publicznie i niepopularnych. W 2003 roku George W. Bush, aby umotywować działania podjęte $\mathrm{w}$ Iraku, podkreślił, że

terroryści i ich radykalni sojusznicy, którzy doprowadzili do zamachu 11 września, zaatakowali także niewinnych ludzi na Bliskim Wschodzie. Przekonali się jednak, że wolne narody nie są słabe. Odkąd Ameryka ugasiła ogień z 11 września, opłakała zmarłych i poszła na wojnę, historia się zmieniła. Podjęliśmy walkę z wrogiem. Pozbyliśmy się zagrożenia terrorystycznego dla całej cywilizacji. Nie gdzieś na marginesie ich [terrorystów - K.L.] wpływu, ale w samym sercu ich władzy [w Iraku - K.L. $]^{73}$.

Podobnej argumentacji używał Tomasz Malinowski (podsekretarz stanu USA do spraw demokracji, praw człowieka i pracy), gdy wskazywał wydarzenia z 11 września jako powód utworzenia Guantanamo: „po 11 września zrobiliśmy rzeczy, pewnie zrozumiałe w tamtej sytuacji, jak założenie obozu w bazie Guantanamo"74.

\section{Ramy interpretacyjne „terroryzm” i „terrorysta islamista”}

„Ataki terrorystyczne są często starannie wyliczone i zaplanowane tak, by przyciągnąc uwagę międzynarodowych mediów elektronicznych i prasy"75 — do ta-

71 P. Łepkowski, 11 września 2001 roku: Dzień, który zmienit świat, „Rzeczpospolita” 11.09.2020, https://www.rp.pl/Historia/309099993-11-wrzesnia-2001-roku-Dzien-ktory-zmienil-swiat.html (dostęp: 1.06.2021).

${ }^{72} \mathrm{~K}$. Turecki, Bill Clinton dzień przed atakiem na World Trade Center: mogłem zabić Osame bin Ladena, 2014, https://wiadomosci.onet.pl/tylko-w-onecie/bill-clinton-dzien-przed-atakiem-na-world-trade-center-moglem-zabic-osame-bin-ladena/7cxbb (dostęp: 1.06.2021).

73 Transcript of President Bush's, War on Terror, 2003, https://2001-2009.state.gov/p/nea/rls/ $\mathrm{rm} / 23897$.htm?fbclid=IwAR1GTO2OsoN1N1YajZO-b9CXGDnNt19nM2BZ1YIIaSRLbUjOh4RB792rN-c (dostęp: 1.06.2021).

${ }^{74}$ M. Ostrowski, Podsekretarz stanu USA o potrzebie zwycięstwa demokracji, „Polityka” 2016, https://www.polityka.pl/tygodnikpolityka/swiat/1677612,1,podsekretarz-stanu-usa-o-potrzebie-zwyciestwa-demokracji.read (dostęp: 1.06.2021).

75 K. Maniszewska, Dlaczego terroryści potrzebuja mediów?, https://www.civitas.edu.pl/pl/ kontakt/informacje-prasowe/dlaczego-terrorysci-potrzebuja-mediow-informacja-prasowa (dostęp: 1.06.2021). 
kiego wniosku doszedł już w latach siedemdziesiątych Brian Michael Jenkins. $\mathrm{O}$ ile we wspomnianych latach o atrakcyjności wydarzenia stanowiły wymiar polityczny, sprawa, o którą walczą terroryści (zamach nad Lockerbie 1988 roku, atak w Monachium w 1972 roku), czy po prostu liczba ofiar, o tyle w późniejszym czasie (od zamachów z 2001 roku) każdy przejaw aktywności będący działaniem terrorystów lub wpisujący się w charakter terrorystycznej aktywności i metod ich działania, skupia uwagę mediów. Terroryzm jest medialny, zatem media, podążając za sensacją, fałszywie kontekstualizują oraz nadają rangę wydarzeniom, tym samym często realizują założenia samych terrorystów. Dzięki mediom poznaliśmy opinię bin Ladena o francuskim zakazie noszenia hidżabów, dowiedzieliśmy się o proklamowaniu kalifatu w Mosulu w 2014 oraz mogliśmy zobaczyć podziękowania Baghdadiego za zamachy na Sri Lance w 2019 roku. Osadzając wydarzenia, często niewłaściwie, w kontekście terrorystycznym, media pokazują odbiorcom, że „ciągle coś się dzieje”, tym samym nadbudowują ramy interpretacyjne „terroryzm” i „terrorysta-islamista”. W konsekwencji każdy kolejny zamach z automatu przypisywany jest islamistom. Dobrym przykładem są wydarzenia na norweskiej wyspie Utøya w 2011 roku $^{76}$ czy moście Westminsterskim w Londynie w $2017^{77}$, kiedy media w pierwszych godzinach po zamachu jasno wskazały winnych - terrorystów islamskich, mimo iż nie znaleziono powiązań $\mathrm{z}$ islamistami. Innym przykładem jest wydarzenie z niemieckiego Münster, kiedy furgonetka wjechała w tłum ludzi na tamtejszym rynku. Media automatycznie uruchomiły ramę ataku terrorystycznego islamskiego samotnego wilka, podczas gdy w rzeczywistości sprawcą był chory psychicznie Niemiec, niemający żadnych powiązań z terrorystami.

Terroryzm jako zjawisko zakotwiczone w kulturze, trudne do zdefiniowania, a dzięki temu pojemne zakresowo, jest „wygodnym” pojęciem zarówno dla mediów, jak i władzy. W tej części artykułu interesować nas będzie szczególnie ten drugi aspekt. Nawiązywanie do terroryzmu w określonych kontekstach pozwala walczyć z opozycją, kontrolować strach społeczeństwa, wskazywać wrogów (także społecznych), legitymizować decyzje polityczne, a w konsekwencji tych działań eliminować opozycję i budować państwo nadzoru i kontroli.

W listopadzie 2015 roku w Paryżu doszło do serii zamachów terrorystycznych zorganizowanych przez ISIS. W atakach zginęło ponad 130 osób, a ponad 300 zostało rannych. Ten oraz inne zamachy dokonywane w Europie (na przykład w Nicei, Londynie, Manchesterze) były szeroko komentowane przez polityków. Odno-

76 M. Szaniewski, B. Węglarczyk, Tragedia w Norwegii. Co najmniej 93 osoby zginęty w zamachach, 2011, http://wyborcza.pl/1,75399,9995175,Tragedia_w_Norwegii_Co_najmniej_93_osoby_ zginely.html (dostęp: 17.05.2021).

77 T. Batchelor, Khalid Masood: London attacker had no links to Isis or al-Qaeda, says Met Police, 2017, https://www.independent.co.uk/news/uk/home-news/khalid-masood-london-attackisis-al-qaeda-no-links-police-a7652696.html (dostęp: 11.05.2021). 
sząc się do zamachów, podkreślali oni gotowość do pomocy oraz przynależność do wspólnoty - walczącej z terroryzmem. Angela Merkel zapewniła Francuzów „My, wasi niemieccy przyjaciele, jesteśmy blisko z wami [...] Odpowiedzmy terrorystom, wierząc z jeszcze większą pewnością siebie w nasze wartości i potwierdzając obowiązywanie tych wartości w całej Europie - teraz jeszcze dobitniej niż kiedykolwiek" 78 . Polscy politycy także wskazywali na potrzebę zjednoczenia w walce: „Francja jest na pierwszej linii frontu walki z terroryzmem, ale to walka wszystkich Europejczyków”79 (Donald Tusk); „Unia Europejska musi zjednoczyć się w skutecznej walce przeciwko terroryzmowi" 80 (Beata Szydło po zamachach w Brukseli).

Mimo wskazanej potrzeby zjednoczenia rama ta wykorzystywana jest także w przypadku przeciwstawiania się Unii Europejskiej do porównywania działań wspólnoty europejskiej z działalnością o charakterze terrorystycznym. Antoni Macierewicz zarzuca UE działania skierowane przeciwko Polsce, wskazując, że „terroryzm jest stosowany jako narzędzie wobec państw Europy. Są tacy, którzy uważają, że Polska niepodległa nie ma racji bytu, że powinna stać się częścią jednorodnego organizmu" 81 . Z kolei Beata Szydło w swoich wypowiedziach połączyła „terroryzm” z kryzysem imigracyjnym: „Bardzo często słyszę w UE — nie łączmy polityki migracyjnej z tym, co dzieje się z terroryzmem. Ale nie da się tego nie łączyć. Ta fala migracji, która ruszyła na Europę, niestety przyniosła również tych, którzy chcą wykorzystywać ludzi szukających pomocy" ${ }^{\prime 2}$. Limity przyjmowanych uchodźców ustalone przez UE w 2015 roku, niewpisujące się w politykę PiS, były szeroko komentowane przez jej przedstawicieli, przy jednoczesnym uruchamianiu ram ,terroryzm” $i$,terrorysta-islamista”. W jednym z artykułów Jakub Bierzyński napisał: „Utożsamienie uchodźców z terrorystami to majstersztyk speców od propagandy PiS" "83. Zarówno konteksty wypowiedzi polityków PiS, jak i ich cele były zróżnicowane. Chcąc straszyć obywateli falą imigrantów, Mariusz

78 B. Cöllen, Angela Merkel oferuje Francji pomoc. „,Odpowiedzmy terrorystom”, 2015, https:// www.dw.com/pl/angela-merkel-oferuje-francji-pomoc-odpowiedzmy-terrorystom/a-18849749 (dostęp: 1.06.2021).

79 Tusk: nie możemy pozwolić, by terroryści odnieśli swoje cele, Onet 2015, https://wiadomosci.onet.pl/swiat/tusk-nie-mozemy-pozwolic-by-terrorysci-odniesli-swoje-cele/r2c8ql (dostęp: 1.06.2021).

80 M. Wilgocki, Zamachy w Brukseli: Samobójcami było dwóch braci. Urodzili się w Belgii, 2016, https://wyborcza.pl/relacje/14,126862,19803663.html (dostęp: 1.06.2021).

81 Macierewicz u Rydzyka: Jesteśmy wielka ofiara terroryzmu, „Newsweek” 2016, https://www. newsweek.pl/polska/macierewicz-polska-pierwsza-ofiara-terroryzmu/k54g273 (dostęp: 1.06.2021).

82 S. Grela, Znów zagraniczna gafa premier Szydto: zamachy sa dlatego, że Europa wpuszcza uchodźców. Fakty i Brytyjczycy temu przeczą, 2017, https://oko.press/zagraniczna-gafa-zamachy-sa-dlatego-ze-wpuszczamy-uchodzcow-fakty-brytyjczycy-temu-przecza/ (dostęp: 3.06.2021).

83 J. Bierzyński, Uchodźcy: najskuteczniejszy straszak władzy, „Polityka” 2017, https://www. polityka.pl/tygodnikpolityka/kraj/1710746,1,uchodzcy-najskuteczniejszy-straszak-wladzy.read (dostęp: 1.06.2021). 
Błaszczak podkreślał, że „dokładne sprawdzanie (migrantów) jest niemożliwe. Świadczy o tym fakt, że wśród terrorystów, którzy zorganizowali zamach w Paryżu, było dwóch, którzy zostali zarejestrowani jako uchodźcy na greckiej wyspie Lesbos" ${ }^{84}$. Dodał przy tym, że „Polska jest bezpieczna, bo nie mamy społeczności muzułmańskich, które stanowią naturalne zaplecze dla terrorystów islamskich, oraz robimy wszystko, żeby była bezpieczna i nie godzimy się na przyjmowanie uchodźców" ${ }^{95}$. W podobnym tonie wypowiadał się Gábor Vona, przewodniczący węgierskiej partii Jobbik, w trakcie debaty nad kwestią relokacji uchodźców. Zaznaczał, że , nie wszyscy imigranci są terrorystami, ale każdy terrorysta jest imigrantem" 86 , wpisując się w antyimigracyjny dyskurs narzucany przez Victora Orbána. Kryzys imigracyjny pozwolił także partii rządzącej postawić się w roli gwaranta instytucji walczącej o bezpieczeństwo Polaków:

Jeżeli nie dostrzegacie tego, że zagrożenie terrorystyczne jest faktem, który każdego dnia może dotknąć każde państwo w Europie, i uważacie, że Polska nie powinna się bronić, to idziecie ręka w rękę z tymi, którzy wymierzają tę broń przeciwko Europie, przeciwko nam wszystkim. [...] ten rząd nie dopuści do tego, by polskie dzieci nie mogły pójść bezpiecznie do klubu, na plac zabaw i do szkoły [...]. I znowu nie akceptując przymusowej relokacji migrantów, wygrywamy bezpieczeństwo własnych obywateli. Ludzie w Polsce, w miejscach publicznych, czują się bezpiecznie, a przynajmniej dużo bezpieczniej niż na zachodzie Europy” (Beata Szydło).

Co ciekawe, rama „terroryzm islamski”, funkcjonująca w kontekście kryzysu imigracyjnego, uruchamiana była także w sytuacjach na pozór niezwiązanych z polityką. Warto tu wspomnieć o liście radnego PiS Filipa Frąckowiaka do Hanny Gronkiewicz-Waltz, dotyczącym warsztatów przyrodniczo-matematycznych w Warszawskim Domu Kultury. Autor uważał „za niestosowne, by w dniach, gdy islamski terroryzm atakuje europejskie miasta, zabija niewinnych ludzi [...], uczyć nasze dzieci wiązania tradycyjnych islamskich strojów. Stroje te są nierzadko używane przez terrorystów, którzy odnajdują obowiązek ich ubioru w Koranie" 87 . Powyższy przykład z jednej strony wpisuje się w narrację, w której PiS łączy uchodźców z terroryzmem, z drugiej cechuje go wykorzystanie ramy do deprecjonowania innych kultur.

84 Oko.press, Prawda czy fatsz?, https://oko.press/wypowiedzi/blaszczak-leros12/ (dostęp: 3.06.2021).

85 „Niewatpliwie atak terrorystyczny”. Błaszczak: Polska jest bezpieczna, Wirtualna Polska 2017, https://wiadomosci.wp.pl/niewatpliwie-atak-terrorystyczny-blaszczak-polska-jest-bezpieczna-6156274194245761a (dostęp: 3.06.2021).

${ }^{86}$ B. Novak, „Europe has been attacked” says Viktor Orbán, 2015, https://budapestbeacon. com/europe-has-been-attacked-says-viktor-orban/?fbclid=IwAR0u39Nq8-JOx8ZehJqtYEqMfQ3ei7kgPozSY6URcYtTGClaS4gxqrTBGU4 (dostęp: 3.06.2021).

${ }^{87}$ K. Słowik, ,, Geometria w strojach arabskich”? Zajęcia nie spodobały się radnemu PiS, 2017, https://warszawa.wyborcza.pl/warszawa/7,54420,21981982,geometria-w-strojach-arabskich-zajecia-nie-spodobaly-sie.html (dostęp: 3.06.2021). 
Kolejnym istotnym kontekstem użycia opisywanych ram jest walka z szeroko pojętą opozycją. Po zatrzymaniu przez służby w 2021 roku Aleksieja Nawalnego przez rosyjskie ulice przetoczyła się fala manifestacji będących formą wsparcia dla opozycjonisty. W konsekwencji moskiewska prokuratura wystąpiła z wnioskiem o wpisanie założonej przez Nawalnego Fundacji Walki z Korupcją oraz jej biur regionalnych na listę organizacji terrorystycznych (wraz z na przykład ISIS), argumentując, że „Organizacje te pod pozorem liberalnych haseł pracują nad stworzeniem warunków do destabilizacji sytuacji społecznej i społeczno-politycznej w Rosji. [...] Prawdziwym celem ich działań jest stworzenie warunków do zmiany podstaw porządku konstytucyjnego, w tym wykorzystanie scenariusza kolorowej rewolucji" ${ }^{88}$. Podobne wypowiedzi padają również z ust rodzimych polityków. Według przedstawicieli rządu w Polsce „terroryzm” może być stosowany i wspierany przez opozycję. Witold Waszczykowski w 2017 w kontekście protestów przeciwko upartyjnieniu sądów, zaznaczał „że dojdzie do jakiegoś terroru słownego, retorycznego, a skończy się, być może, jakimiś akcjami terrorystycznymi przeciwko państwu polskiemu" ${ }^{\circ 9}$. Z kolei Jarosław Kaczyński podczas uchwalania ustawy antyterrorystycznej zarzucał opozycji: „kiedyś, mając poparcie wymiaru sprawiedliwości, broniliście złodziei, teraz bronicie terrorystów" $" 90$. Aspekt legitymizacji działań władzy poprzez „straszenie terroryzmem” także należy uznać za istotny. Trump w styczniu 2017 roku, komentując amerykańską politykę wizową, zaznaczył, że dżihadyści z 11 września przybyli do USA, mimo że byli na celowniku służb, i potem spokojnie czekali na rozkaz ataku już po wygaśnięciu wiz ${ }^{91}$. Kilka miesięcy później powiedział, że „radykalny islamski terroryzm musi zostać powstrzymany za pomocą wszelkich niezbędnych środków!"92. Sądy muszą nam przywrócić nasze prawa ochronne. W podobnym tonie za zaostrzeniem prawa wypowiadali się Marine Le Pen, uznająca, że ustawa o terroryzmie musi zmierzać

88 Rosja. Prokuratura chce uznania zwolenników Nawalnego za terrorystów, Polsat News 2021, https://www.polsatnews.pl/wiadomosc/2021-04-16/rosja-prokuratura-chce-uznania-zwolennikow-nawalnego-za-terrorystow/ (dostęp: 3.06.2021).

89 S. Grela, Robi się groźnie. Min. Waszczykowski ogłasza, że opozycja planuje ataki terrorystyczne, 2017, https://oko.press/robi-sie-groznie-min-waszczykowski-oglasza-ze-opozycja-planuje-ataki-terrorystyczne/ (dostęp: 3.06.2021).

90 Burzliwa debata przed glosowaniem ws. ustawy antyterrorystycznej. Kaczyński: Kiedyś mając poparcie wymiaru sprawiedliwości broniliście złodziei, teraz bronicie, terrorystów, „Dziennik Gazeta Prawna" 2016, https://www.gazetaprawna.pl/wiadomosci/artykuly/951043, ustawa-antyterrorystyczna.html (dostęp: 3.06.2021).

91 J. Goodman, US travel ban: Why these seven countries?, 2017, https://www.bbc.com/news/ world-us-canada-38798588?fbclid=IwAR09MOz5Itg03OLd29qljRxSVQd3bXkgXHWFwuAD3v g5eNvafXgkRDA1wao (dostęp: 3.06.2021).

92 Trump: Stop terrorism by 'whatever means' necessary, BBC 2017, https://www.bbc.com/ news/world-us-canada-40977702 (dostęp: 3.06.2021). 
do wykorzenienia wszelkich manifestacji ideologii islamistycznej ${ }^{93}$, oraz Grzegorz Cieślak (specjalista do spraw terroryzmu), który podkreślał, że „Polsce brakuje narzędzi prawnych pomocnych $\mathrm{w}$ walce $\mathrm{z}$ terroryzmem. Powinniśmy pilnie rozważać ustanowienie ustawy anty terrorystycznej, która zbierze rozproszone dzisiaj akty prawne. Chodzi o rozwiązania prawne umożliwiające karalność przygotowania cywilnych aktów terrorystycznych" 94 . Przyjętej ustawie antyterrorystycznej opozycja zarzucała ,naruszenie i ograniczenie praw obywatelskich i swobód publicznych" ${ }^{95}$. Komentatorzy w mediach podkreślali, że „ustawa pod pretekstem zapobiegania aktom terroru wprowadziła szereg rozwiązań, które niekoniecznie terroryzmowi zapobiegają, za to umożliwiają niekontrolowaną inwigilację [...]. Zapis sugeruje, że za terroryzm będzie uznane znieważenie prezydenta Dudy" ${ }^{96}$.

\section{Podsumowanie}

Głównym celem niniejszego artykułu było wskazanie, jak ramy (frames) medialne stają się elementami zapewniającymi nawiązywalność (stanowiącą jeden z kluczowych selektorów wskazanych w Luhmannowskiej koncepcji mediów) i umożliwiają szybkie uruchomienie w społecznej świadomości tematu terroryzmu. Rama „11 września” (podobnie jak inne frames odnoszące się do współczesnego terroryzmu) nie stanowi jednak odniesienia (nawiązywalności) do wszelakich spektakularnych zamachów terrorystycznych. Konotować ma zamachy podejmowane w szczególności przez islamskich terrorystów, a tym samym uruchamiać szereg skojarzeń związanych z wyglądem, religią czy kulturą zamachowców. Jednocześnie ramy medialne ulegają dekontekstualizacji, co pozwala na ich wykorzystanie w odniesieniu do wydarzeń mających dość nikłe lub niewielkie podobieństwo do tematu głównego. Działa tutaj następujący typ sprzężenia: w pierwszej kolejności w społecznym odbiorze uruchomione mają być określone skojarzenia, na przykład terroryzm, islamista, duża liczba ofiar, zagrożenie, ogromne zniszczenia, a następnie owe asocjacje przenoszone są do zupełnie odmiennego kontekstu, przez co pełnią funkcje legitymizacyjne, perswazyjne czy też retoryczne.

93 A. Sulzer, Le FN a toujours une bonne raison de ne pas voter les lois antiterroristes, 2017, https://www.lexpress.fr/actualite/politique/fn/le-fn-a-toujours-une-bonne-raison-de-ne-pas-voterles-lois-antiterroristes_1949127.html (dostęp: 3.06.2021).

94 Cieślak: potrzebna ustawa antyterrorystyczna. Przepiórka: system bezpieczeństwa zaczyna się w domu. Konieczna edukacja, TVP Info 2015, https://www.tvp.info/22659754/cieslak-potrzebna-ustawa-antyterrorystyczna-przepiorka-system-bezpieczenstwa-zaczyna-sie-w-domu-konieczna-edukacja (dostęp: 3.06.2021).

95 Ustawa antyterrorystyczna przyjęta. Co to oznacza?, „Business Insider” 2016, https://businessinsider.com.pl/wiadomosci/sejm-uchwalil-ustawe-o-dzialaniach-antyterrorystycznych/b2 w 5hb4 (dostęp: 3.06.2021).

96 W. Łączewski, Dlaczego ustawa antyterrorystyczna jest niebezpieczna, „Polityka” 18.07.2017, https://www.polityka.pl/tygodnikpolityka/kraj/1712526,1,dlaczego-ustawa-antyterrorystyczna-jest-niebezpieczna.read (dostęp: 3.06.2021). 
Biorąc pod uwagę sprzężenie strukturalne funkcjonujące między systemem mediów i polityki, należy zauważyć, że ramy generowane przez media są jednak nie tylko wykorzystywane w treściach generowanych przez media, lecz także „zapożyczane", rozbudowywane i wykorzystywane w komunikacji politycznej, na przykład $\mathrm{w}$ celu nadawania rangi innym wydarzeniom o charakterze terrorystycznym, w szczególności tym, do których doszło w krajach nieleżących w centrum geopolitycznych rozgrywek. Nawiązywalność i nadawanie rangi danym wydarzeniom służyć ma niejednokrotnie wprowadzaniu do komunikacji postulatów dotyczących zwiększania uprawnień aparatu przymusu i ograniczania wolności obywatelskich.

Wspomniana dekontekstualizacja ram sprawia, że stają się one uniwersalnym „środkiem komunikacyjnym”. Ulokowane w kontekście politycznych sporów, w szczególności w kontekście kodu rządzący/opozycja, pozwalają na atakowanie działań i decyzji podejmowanych przez poprzedników, budowanie pozytywnego wizerunku przez „odwracanie złych decyzji” podejmowanych przez wcześniejsze rządy, stanowią skuteczne narzędzie do personalnych rozgrywek w obrębie zarówno własnego, jak i zewnętrznego środowiska politycznego.

Wreszcie rama ta służyć może jako sposób podkreślania wszelkiego rodzaju strat (finansowych, infrastrukturalnych) lub jako zdarzenie pozwalające wywołać efekt „,czegoś wielkiego”, „,zegoś niespotykanego”. Mimo iż liczba ofiar wirusa SARS-CoV-2 w Stanach Zjednoczonych wielokrotnie przekroczyła liczbę ofiar zamachów z 11 września, to nie ma innego, równie tragicznego wydarzenia funkcjonującego w społecznej świadomości, więc zamachy na WTC wskazywane są przez polityków częściej niż porównania z pandemią grypy hiszpanki. Wynikać to może z faktu, że 11 września jest wspomnieniem wciąż świeżym w przeciwieństwie do pandemii hiszpanki.

Biorąc pod uwagę zaprezentowane w artykule przykłady, należy podkreślić, iż analizowanie ofert medialnych nie powinno ograniczać się do badania, jakie ramy interpretacyjne wykorzystywane są przez media do informowania społeczeństwa o wydarzeniach, ale również powinno obejmować refleksję o tym, jak owe ramy są przejmowane i wykorzystywane przez inne systemy sprzężone funkcjonalnie z systemem mediów. Wykorzystywanie określonych ram przekłada się bowiem na generowanie określonych wizji świata w społecznej świadomości, a tym samym na legitymizację i normalizację określonych decyzji, wartości i postulatów politycznych.

\section{Bibliografia}

Brunkard J., Namulanda G., Ratard R., Hurricane Katrina Deaths, Louisiana, 2005, „Disaster Medicine and Public Health Preparedness" 2, 2008, nr 4, https://www.cambridge.org/core/journals/ disaster-medicine-and-public-health-preparedness/article/hurricane-katrina-deaths-louisiana-2005/8A4BA6D478C4EB4C3308D7DD48DEB9AB (dostęp: 30.05.2021). 
Casale D., Institutional and Legal Aspects of UE Counter-Terrorism, „Legal Aspects Combating of Terrorism" 2008, nr 47.

Centers for Disease Control and Prevention, Deaths in World Trade Center Terrorist Attacks - New York City, „Morbidity and Mortality Weekly Report” (Weekly Special Issue) 51, 2002, nr 16-18, http://www.cdc.gov/mmwr/preview/mmwrhtml/mm51spa6.htm.

Decyzja ramowa Rady Europejskiej z 13 czerwca 2002 roku w sprawie zwalczania terroryzmu, Dz.Urz. UE 2002/475/WSiSW, s. 19, http://eur-lex.europa.eu/legal-content/EN/TXT/?uri=urise rv:OJ.L_.2002.164.01.0003.01.ENG.

Fleischer M., Media w perspektywie konstruktywizmu, „2K - Kultura i Komunikacja”2005, nr 1-2.

Fleischer M., Ogólna teoria komunikacji, Wrocław 2007.

Lachowska K., Kim jest terrorysta? Sposoby stereotypizacji terrorystów. Analiza wyników badań ankietowych, [w:] Badanie i projektowanie komunikacji 4, Kraków 2015.

Lachowska K., Terroryzm. Definicje i ich funkcje, [w:] Badanie komunikacji, t. 1, Kraków 2018.

Luhmann N., Realność mediów masowych, przeł. J. Barbacka, Wrocław 2009.

Luhmann N., Systemy społeczne. Zarys ogólnej teorii, przeł. M. Kaczmarczyk, Kraków 2007.

Maćkiewicz J., Ramy interpretacyjne jako narzędzie badań medioznawczych, „Studia Medioznawcze" 21, 2020, nr 3.

Madej M., Międzynarodowy terroryzm polityczny, Warszawa 2001.

Maturana R.H., Ontologia obserwacji. Biologiczne podstawy samoświadomości i fizykalna dziedzina egzystencji, [w:] Radykalny konstruktywizm. Antologia, red. B. Balicki, D. Lewiński, B. Ryż, Wrocław 2010.

Matuszek K., Niklasa Luhmanna socjologia bez czlowieka, Kraków 2017.

Rees P., Kolacja z terrorysta. Spotkania z najbardziej poszukiwanymi bojownikami na świecie, przeł. B. Dąbrowa-Kość, G. Kość, Kraków 2008.

Roth G., Poznanie i realność: realny mózg i jego rzeczywistość, [w:] Radykalny konstruktywizm. Antologia, red. B. Balicki, D. Lewiński, B. Ryż, Wrocław 2010.

Schmidt S.J., Konstruktywizm jako teoria mediów, [w:] Konstruktywizm w badaniach literackich, red. E. Kuźma, A. Skrendo, J. Madejski, Kraków 2006.

Skąpska G., Niklasa Luhmanna socjologia religii jako element ogólnej teorii systemu społecznego, [w:] N. Luhmann, Funkcja religii, przeł. D. Motak, Kraków 2007.

Spencer-Brown G., Laws of Form, Portland 1994.

Weinberg L., Pedahzur A., Hirsch-Hoefler S., The Challenges of Conceptualizing Terrorism, „Terrorism and Political Violence" 16, 2004, nr 4.

Wojciechowski S., Terroryzm. Analiza pojęcia, „Przegląd Bezpieczeństwa Wewnętrznego” 2009, nr 1. http://www.abw.gov.pl/portal/pl/92/310/Przeglad_Bezpieczenstwa_Wewnetrznego_1_2009.html.

Zagrożenie terroryzmem, oprac. M. Feliksiak, CBOS, Komunikat z Badań 2015, nr 50.

\section{Źródła internetowe}

America's day of terror: Timeline, 2001, http://news.bbc.co.uk/2/hi/americas/1537785.stm.

Bamber D., Bin Laden: Yes, I did it, http://www.telegraph.co.uk/news/worldnews/asia/afghanistan/1362113/Bin-Laden-Yes-I-did-it.html.

Batchelor T., Khalid Masood: London attacker had no links to Isis or al-Qaeda, says Met Police, https://www.independent.co.uk/news/uk/home-news/khalid-masood-london-attack-isis-al-qaeda-no-links-police-a7652696.html.

Bellver J., , Le 11 septembre français” à la Une du „,Monde”, pas un mot à la Une en deuil de „,M“, https://www.ozap.com/actu/-le-11-septembre-francais-a-la-une-du-monde-pas-un-mot-a-laune-en-deuil-de-m/460911.

Studenckie Prace Prawnicze, Administratywistyczne i Ekonomiczne 38, 2021

(C) for this edition by CNS 
Bendyk E., Wzór na terror, https://www.polityka.pl/archiwumpolityki/1832788,1,wzor-na-terror.read.

Biernacki o zamachu w Tunezji: to polski 11 września, https://tvn24.pl/polska/biernacki-o-zamachu-w-tunezji-to-polski-11-wrzesnia-ra525580.

Bierzyński J., Uchodźcy: najskuteczniejszy straszak władzy, https://www.polityka.pl/tygodnikpolityka/kraj/1710746,1,uchodzcy-najskuteczniejszy-straszak-wladzy.read.

Boot M., I saw $9 / 11$ in New York. This is worse, https://www.washingtonpost.com/ opinions/2020/04/02/i-saw-911-new-york-this-is-worse/.

Breuninger K., New York Gov. Andrew Cuomo says he's 'not that confident' in federal government's handling of coronavirus crisis, https://www.cnbc.com/2020/04/09/coronavirus-update-cuomonot-confident-in-feds-handling-of-crisis.html.

Burzliwa debata przed głosowaniem ws. ustawy antyterrorystycznej. Kaczyński: Kiedyś mając poparcie wymiaru sprawiedliwości broniliście złodziei, teraz bronicie, terrorystów, https://www. gazetaprawna.pl/wiadomosci/artykuly/951043, ustawa-antyterrorystyczna.html.

Central Intelligence Agency, Terrorism FAQs, https://www.cia.gov/news-information/cia-the-waron-terrorism/terrorism-faqs.html.

Cieśla J., Sondaż POLITYKI: czego Polacy boja się najbardziej, https://www.polityka.pl/tygodnikpolityka/kraj/1702906,1,sondaz-polityki-czego-polacy-boja-sie-najbardziej.read.

Cieślak: potrzebna ustawa antyterrorystyczna. Przepiórka: system bezpieczeństwa zaczyna się $w$ domu. Konieczna edukacja, https://www.tvp.info/22659754/cieslak-potrzebna-ustawa-antyterrorystyczna-przepiorka-system-bezpieczenstwa-zaczyna-sie-w-domu-konieczna-edukacja.

Cöllen B., Angela Merkel oferuje Francji pomoc. „,Odpowiedzmy terrorystom”, https://www. dw.com/pl/angela-merkel-oferuje-francji-pomoc-odpowiedzmy-terrorystom/a-18849749.

Crowds Greet USNS Comfort in NYC Monday; Ship to Help Hospitals With Non-Coronavirus Patients, https://www.nbcnewyork.com/news/local/usns-comfort-arrives-in-nyc-monday-to-helphospital-with-non-coronavirus-patients/2350317.

Dżochar Carnajew uznany za winnego zamachu w Bostonie, https://wiadomosci.wp.pl/dzochar-carnajew-uznany-za-winnego-zamachu-w-bostonie-6025268084437633a.

Goodman J., US travel ban: Why these seven countries?, https://www.bbc.com/news/world-us-canada-38798588?fbclid=IwAR09MOz5Itg03OLd29qljRxSVQd3bXkgXHWFwuAD3vg5eN vafXgkRDA1wao.

Grela S., Robi się groźnie. Min. Waszczykowski ogłasza, że opozycja planuje ataki terrorystycz$n e, \quad$ https://oko.press/robi-sie-groznie-min-waszczykowski-oglasza-ze-opozycja-planuje-ataki-terrorystyczne/.

Grela S., Znów zagraniczna gafa premier Szydło: zamachy sq dlatego, że Europa wpuszcza uchodźców. Fakty i Brytyjczycy temu przecza, https://oko.press/zagraniczna-gafa-zamachy-sa-dlatego-ze-wpuszczamy-uchodzcow-fakty-brytyjczycy-temu-przecza/.

Haroun A., Daily COVID-19 death toll in the US passes 3,000 - more than the death toll from the 9/11 tragedy, https://www.businessinsider.com/daily-us-covid-19-deaths-higher-than-911-deathtoll-2020-12?IR=T.

International Terrorism and Security Research, What is Terrorism?, http://www.terrorism-research. $\mathrm{com} /$.

Kaczyński: Smoleńsk jak 11 września; bez ustawy nie wyjaśnimy katastrofy, https://www.tvp. info/14638157/kaczynski-smolensk-jak-11-wrzesnia-bez-ustawy-nie-wyjasnimy-katastrofy.

Łączewski W., Dlaczego ustawa antyterrorystyczna jest niebezpieczna, https://www.polityka.pl/ tygodnikpolityka/kraj/1712526,1,dlaczego-ustawa-antyterrorystyczna-jest-niebezpieczna.read.

Łepkowski P., 11 września 2001 roku: Dzień, który zmienil świat, https://www.rp.pl/ Historia/309099993-11-wrzesnia-2001-roku-Dzien-ktory-zmienil-swiat.html.

Macierewicz u Rydzyka: Jesteśmy wielka ofiara terroryzmu, https://www.newsweek.pl/polska/macierewicz-polska-pierwsza-ofiara-terroryzmu/k54g273. 
Maniszewska K., Dlaczego terroryści potrzebuja mediów?, https://www.civitas.edu.pl/pl/kontakt/ informacje-prasowe/dlaczego-terrorysci-potrzebuja-mediow-informacja-prasowa.

„Niewatpliwie atak terrorystyczny”. Błaszczak: Polska jest bezpieczna, https://wiadomosci.wp.pl/ niewatpliwie-atak-terrorystyczny-blaszczak-polska-jest-bezpieczna-6156274194245761a.

Novak B, „Europe has been attacked” says Viktor Orbán, https://budapestbeacon.com/europe-hasbeen-attacked-says-viktor-orban/?fbclid=IwAR0u39Nq8-JOx8ZehJqtYEqMfQ3ei7kgPozSY6URcYtTGClaS4gxqrTBGU4.

Osborne S., Trump says 'I think I know' who was behind 9/11 attacks, https://www.independent. co.uk/news/world/americas/us-politics/trump-911-iraq-world-trade-center-deep-state-abcnews-interview-a8962081.html.

Ostrowski M., Podsekretarz stanu USA o potrzebie zwycięstwa demokracji, https://www.polityka. pl/tygodnikpolityka/swiat/1677612,1,podsekretarz-stanu-usa-o-potrzebie-zwyciestwa-demokracji.read.

Prawda czy fatsz?, https://oko.press/wypowiedzi/blaszczak-leros12/.

Rosja. Prokuratura chce uznania zwolenników Nawalnego za terrorystów, https://www.polsatnews. pl/wiadomosc/2021-04-16/rosja-prokuratura-chce-uznania-zwolennikow-nawalnego-za-terrorystow/.

Stona Katrina, https://www.polityka.pl/archiwumpolityki/1866434,1,slona-katrina.read?fbclid=Iw AR3t_543YLwFdQJ5hzNVAZzU0S1i0zh7Rb_oZhDV6mOqNshm3MkIfBudbUMPolityka.

Słowik K., ,, Geometria w strojach arabskich”? Zajęcia nie spodobały się radnemu PiS, https:// warszawa.wyborcza.pl/warszawa/7,54420,21981982,geometria-w-strojach-arabskich-zajecianie-spodobaly-sie.html.

Sulzer A., Le FN a toujours une bonne raison de ne pas voter les lois antiterroristes, https://www. lexpress.fr/actualite/politique/fn/le-fn-a-toujours-une-bonne-raison-de-ne-pas-voter-les-lois-antiterroristes 1949127.html.

Szaniewski S., Węglarczyk B., Tragedia w Norwegii. Co najmniej 93 osoby zginęły w zamachach, http://wyborcza.pl/1,75399,9995175,Tragedia_w_Norwegii_Co_najmniej_93_osoby_zginely. html.

Times Square crash: Man charged said he wanted to ,, kill them all”, https://www.theguardian.com/ us-news/2017/may/19/times-square-crash-man-charged-murder.

Transcript of President Bush's address, http://edition.cnn.com/2001/US/09/20/gen.bush.transcript.

Transcript of President Bush's, War on Terror, https://2001-2009.state.gov/p/nea/rls/rm/23897.htm? fbclid=IwAR1GTO2OsoN1N1YajZO-b9CXGDnNt19nM2BZ1YIIaSRLbUjOh4RB792rN-c.

Trump says coronavirus worse 'attack' than Pearl Harbor, https://www.bbc.com/news/world-uscanada-52568405.

Trump: Stop terrorism by 'whatever means' necessary, https://www.bbc.com/news/world-us-canada-40977702.

Turecki K., Bill Clinton dzień przed atakiem na World Trade Center: mogłem zabić Osamę bin Ladena, https://wiadomosci.onet.pl/tylko-w-onecie/bill-clinton-dzien-przed-atakiem-na-world-trade-center-moglem-zabic-osame-bin-ladena/7cxbb.

Tusk: nie możemy pozwolić, by terroryści odnieśli swoje cele, https://wiadomosci.onet.pl/swiat/tusk-nie-mozemy-pozwolic-by-terrorysci-odniesli-swoje-cele/r2c8ql.

U.S. Department of Justice. Federal Bureau of Investigation, Terrorism 2000/2001, http://www.fbi. gov/stats-services/publications/terror.

U.S. Department of Justice. Federal Bureau of Investigation, Terrorism 2002-2005, https://www.fbi. gov/stats-services/publications/terrorism-2002-2005.

Ustawa antyterrorystyczna przyjęta. Co to oznacza?, https://businessinsider.com.pl/wiadomosci/ sejm-uchwalil-ustawe-o-dzialaniach-antyterrorystycznych/b2w5hb4.

Studenckie Prace Prawnicze, Administratywistyczne i Ekonomiczne 38, 2021

(C) for this edition by CNS 
Wilgocki M., Zamachy w Brukseli: Samobójcami było dwóch braci. Urodzili się w Belgii, https:// wyborcza.pl/relacje/14,126862,19803663.html.

Williams P., On the U.S.N.S. Comfort, the Fight Changes Constantly, https://www.newyorker.com/ magazine/2020/04/27/on-the-usns-comfort-the-fight-changes-constantly.

Zamach na muzeum $w$ Tunisie — raport, https://tvn24.pl/raporty/zamach-na-muzeum-w-tunezji-rr962-2595701. 